\title{
Non classical HLA genes and non-HLA genes in a population of infants at familial risk of atopy
}

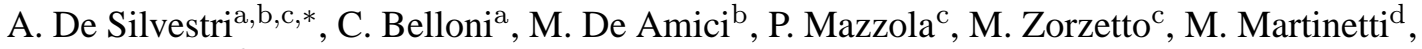 \\ L. Salvaneschi ${ }^{\mathrm{d}}$ and M. Cuccia ${ }^{\mathrm{c}}$ \\ ${ }^{a}$ Division of Neonatology, IRCCS Policlinico San Matteo, Pavia, Italy \\ ${ }^{\mathrm{b}}$ Pediatrics Department, IRCCS Policlinico San Matteo, Pavia, Italy \\ ${ }^{\mathrm{c}}$ Genetics and Microbiology Department, University of Pavia, Italy \\ ${ }^{\mathrm{d}}$ Immunohematology and Transfusion Service, IRCCS Policlinico San Matteo, Pavia, Italy
}

\begin{abstract}
Aim: We investigated on parental history and IgE serum level in 2588 consecutive newborns to individuate babies "at risk" of atopy at birth and we analysed the polymorphisms of class III region to evaluate the association with immunogenetic markers of HLA: C4A, C4B, LTA, RAGE and TNFA genes; we performed TNF and IgE receptor (FCERB1) physiologically related gene polymorphisms.

Result: 791 babies/2588 (30.6\%) were considered "at risk" for atopy and followed-up: 400 had familial history of atopy (at least one parent or sibling), $256 \mathrm{had} \operatorname{IgE}>0.35 \mathrm{kUA} / \mathrm{l}$ at birth and during the follow-up and 135 were positive for both conditions.

The allele C4B2 was significantly more frequent in the sample of babies at risk $(22.1 \%$ vs $10 \%, p<0.001)$. Furthermore, the mean value of IgE at birth in babies carrying the allele C4B2 was $2.26 \mathrm{KUA} / 1$ versus $0.74 \mathrm{KUA} / 1$ in those not carrying this allele $(p=0.01)$. No significant association emerged for RAGE at the centromeric end of class III region and for LTA, TNFA at the telomeric one. TNFRI, TNFRII and FCERB1 gene polymorphisms also seemed not implicated.

Conclusion: Our study confirms that HLA class III region seems involved in familial predisposition to atopy, and C4B gene probably acts as a marker of a more restricted subregion.
\end{abstract}

\section{Introduction}

The incidence, prevalence and severity of atopic disease are increasing in our industrialised countries: it seems of peculiar interest understanding the ethiology of this condition finalised to the prevention. Relationship among IgE hyperproduction and genetic predisposition or environmental influences have already been demonstrated [1]. It is well known that babies of atopic parents are at high risk of developing atopic diseases; however, the phenotypic expression of such diseases

*Corresponding author: De Silvestri Annalisa, Genetics and Microbiology Department, Via Abbiategrasso 207, 27100 Pavia, Italy. Tel.: +39 0382 503864; Fax: +39 0382 503568; E-mail: a.desilvestri@smatteo.pv.it. varies widely, as atopy is a heterogeneous state, probably determined by genetic and environmental interactions.

Atopic disease is often mediated by the production of immunoglobulin E (IgE) and is characterized by predominance of Th2 pathway activation. Neonates with a familial risk of IgE-mediated allergy have a significantly decreased production in cord blood of the Th1 cell secreted cytokines, IFN- $\gamma$ and TNF- $\alpha$, that could be correlated with atopy later in life $[2,3]$.

Several investigators have provided evidence for a genetic susceptibility of atopy [4]. Despite evidence of heritability, it has been difficult to determine genetic markers that predispose individuals. Many studies have attempted to identify an association between this condition and immune genes and in particular with 
HLA genomic region, given its role in regulating the immune response. In particular MHC (chromosome 6p21.3) was considered to be a major locus influencing immunoglobulin levels: IgA deficit [5,6] and modulation of total serum IgE [7]. HLA class II polymorphism is variably associated with sensitisation to specific allergens, but few convincing data supporting association of HLA class II with asthma or general state of atopy, emerged [8]. Associations of asthma with HLA class III polymorphisms, in particular with Tumor Necrosis Factor (TNF), were also proposed. TNF- $\alpha$, a potent pro-inflammatory cytokine, was found in excess in asthmatic airways $[9,10]$, but these results emphasize the inflammatory nature of the asthmatic response as a distinct fact from its allergic basis [11].

In order to individuate babies "at risk" of atopy at birth we enrolled and follow-up all newborn with $\operatorname{IgE}>$ $0.35 \mathrm{KU} / \mathrm{l}$ and/or familial history of atopy and we want to evaluate the association between these risk conditions and immunogenetic markers of HLA class III region (6p21.3): receptor advanced glycation end products (RAGE), complement serum component 4 (genes C4A and C4B), Lymphotoxin alpha (LTA), and TNFA genes. HLA class III region contains about 70 structural genes spanning $1100 \mathrm{~Kb}$ of genomic DNA in an unusually dense arrangement. The physiological role of many class III products are yet to be clearly determined, but many diseases (autoimmune, neurological, endocrinological and malignant) have been associated with this subregion [12-17]. Studying these polymorphisms could be useful to better understand the molecular basis of many diseases. Several genes located within HLA class III are not "immune response" genes but are critical for growth, development and differentiation as they code for receptors, extracellular matrix proteins and transcriptional factors [17-22]. Furthermore we investigated TNF and IgE receptor physiologically related genes coding for TNF receptor I (TNFRI $12 \mathrm{p} 13$ ) and II (TNFRII 1p36) and $\beta$ subunit of the highaffinity IgE receptor (FCERB1 11q13) [23,24]. We presented HLA class II polymorphisms of DRB1 locus in 4 unrelated families of babies carrying the allele C4B2 and hyperIgE from birth and history of atopy, in order to better define the inheritance by descent of classical HLA predisposing genes.

\section{Materials and methods}

\subsection{Identification and follow up of babies at risk}

We investigated familial history of atopy and evaluated total serum $\operatorname{IgE}$ at birth in 2588 consecutive full term healthy newborns at the Division of Neonatology from January 2001 to June 2003 whose parents signed informed consent. 127 babies born in Pavia (4.7\%) in the same period were not tested for lack of parental consent. Babies with parents or a sibling suffering for allergic dermatitis, rhynitis or asthma and babies with total serum IgE $>0.35 \mathrm{KU} / \mathrm{L}$ were considered "at risk" and followed up: a blood sample was drawn every six months to evaluate total IgE level and specific $\operatorname{IgE}$ to a panel of food or inhalants allergens. The total IgE have been carried out by fluoroenzymeimmunoassay (Pharmacia CAP System FEIA. Uppsala, Sweden). IgE calibrators, traceable to the WHO preparation 75/502 for Human IgE, are used for the determination of total IgE and values are expressed in kU/l.

Atopy screening test (Phadiatop ${ }^{\circledR}$ ) and multi-allergen tests (Fx5) are expressed as positive or negative using the specific IgE calibrator $0.35 \mathrm{kU} / \mathrm{l}$ as cut-off.

\subsection{Genetic study design}

The typing of $\mathrm{C} 4$ polymorphisms was planned in a subsample of 6 month-old babies scheduled for the follow-up visit in September-December 2001: thus the allele frequencies of C4A and C4B genes were evaluated in 61 Caucasian (Northern Italy) consecutive babies "at risk" who show-up at the visit out of 92 infants scheduled. At the follow-up visit, scheduled at 12 months, 35 of the 61 babies already typed for C4A and C4B at 6 months of age were typed for RAGE, LTA, TNFA, FCERB1, TNFRI and TNFRII. The remaining 26 were lost to follow-up.

To avoid Bonferroni correction for multiple tests we retested all the significant associations in an independent sample: inclusion criteria were the same of the first sampling (being at risk of atopy and being scheduled for 6 month visit in the period selected for the genetic study enrollment). 34 consecutive babies were enrolled at the 6 month visit in April-May 2002 (C4A and B typing). Sixteen babies scheduled for 6-month visit did not show-up and were not tested. 23 of these babies show up at the follow-up visit of 12 months and were typed for TNFRI in October-November 2002 (Fig. 1).

\subsection{Controls}

Gene frequencies of the babies at risk were compared with those of 245 blood donors of the same area (Pavia province). There were 112 females $(46 \%)$, this frequency is quite similar to the one observed in our sam- 


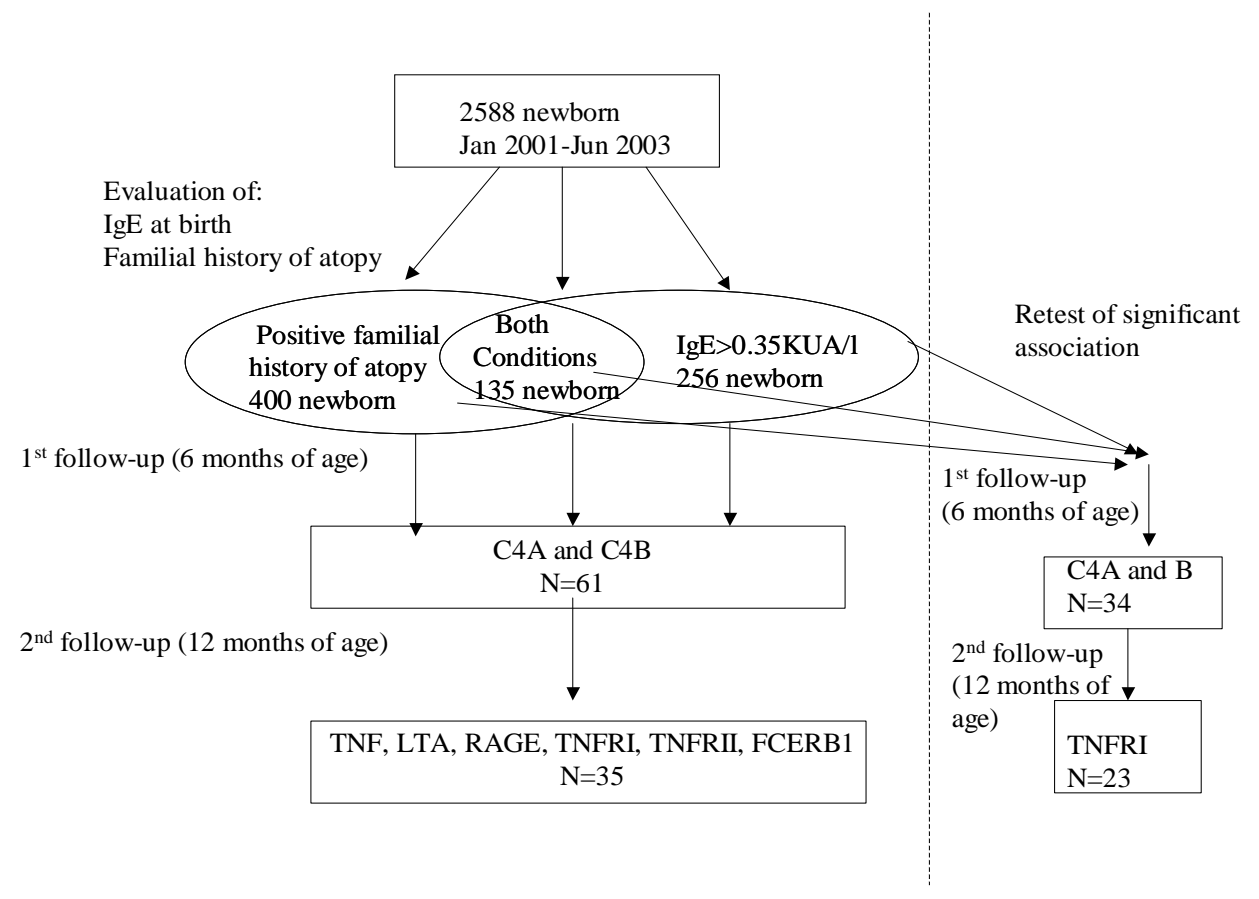

Fig. 1. Study design.

ple of infants (female: $47.3 \%$ ). Mean age was 35 years, obviously older than our baby sample, but difference in genotype distribution in different age class has not been reported; so we prefer to use healthy blood donors without atopic disorders than other babies at birth. For the second sample of babies used to retest the significant associations we enrolled as controls 153 umbilical cord blood donors of our cord blood bank at the Transfusional center, born in Pavia to ensure homogeneity also with age. All babies were $\operatorname{IgE}<0.35 \mathrm{KU} / \mathrm{L}$ at birth and blood samples were drawn at age of six months during routine examination.

\subsection{Genetic polymorphisms}

$C 4 A$ and $C 4 B$ polymorphisms were investigated at proteinic level. Samples of serum were conserved in EDTA, treated with carboxipeptidase and neuroaminidase and electrophoresed onto agarose gel with high voltage. The allelic proteinic bands were underlined after immunofixation with polyclonal antibodies anti-human $\mathrm{C} 4$ and Coomassie blue painting. The electrophoretic bands were subjected to densitometric analysis in order to define null alleles, hetero and homoduplications, as suggested by Mauff [25]. C4A and C4B genes code for two serum isophorms [12-14] and the polymorphism had been associated with many disorders [15-22].
These polymorphisms were investigated at genomic level:

$L T A+252 G>A$ : RFLP obtained by NcoI restriction according a method modified from Ozaki [26] using primer F: 5'-CCGTGCTTCGTGCTTTGGACTA-3', primer R: 5'-AGAGCTGGTGGGGACATGTCTTC-3.

$R A G E-374 T>A$ : RFLP obtained by Tsp509I restriction according a method modified from modified from Hudson [27] using the primers RAGE PROF: 5'CCTGGGTTTAGTTGAGAATTTTTT-3' and RAGE PROR: 5'-GAAAGGCACTTCCTGGGTTCT-3'.

$T N F A-308 G>A$ : RFLP obtained by NcoI restriction according a method modified from Sakao [28] using the primers TNFRE3: 5'-AAAGTTGGGGACAC ACAA-3', TNFU2: 5'-AAATGGAGGCAATAGGTT TTGAGGGCC-3'.

TNFRI +36 A $>G$ : RFLP obtained by MspAII restriction according a method modified from Pitts [29] using primer $\mathrm{F}$ : 5'-GAGCCCAAATGGGGGGAGTG AGAGG-3' and primer R: 5'-ACCAGGCCCGGGCA GGAGAG-3'.

TNFRII $+196 T>G$ : RFLP obtained by NlaIII restriction according a method modified from AlAnsari [30] using primer F: 5'-ACTCTCCTATC CTGCCTGCT-3', primer R: 5'-TTCTGGAGTTGG CTGCGTTTGT3'.

FCERB1 $-109 C>/ T$ : RFLP according the method by Hizawa [31] using primer sense: 5'- 
Table 1

(a) $\mathrm{C} 4 \mathrm{~A}$ and $\mathrm{C} 4 \mathrm{~B}$ polymorphism study in infants and controls

\begin{tabular}{lll}
\hline Allele & Babies "at risk" & Controls \\
\hline C4A0 & $4(3 \%)$ & $39(11 \%)$ \\
C4A2 & $2(2 \%)$ & $36(10 \%)$ \\
C4A3 & $116(95 \%)$ & $260(73 \%)$ \\
C4A5 & 0 & $7(2 \%)$ \\
C4B0 & $10(8 \%)$ & $52(15 \%)$ \\
C4B1 & $85(70 \%)$ & $269(75 \%)$ \\
C4B2 & $27(22 \%)$ & $35(10 \%)$ \\
\hline$*$ &
\end{tabular}

(b) C4B2 allele distribution in different categories analysed

\begin{tabular}{|c|c|c|c|c|c|}
\hline Allele & $\begin{array}{c}\text { Babies with IgE } \\
>0.35 \mathrm{KUA} / 1\end{array}$ & $\begin{array}{c}\text { Babies with familial } \\
\text { history of atopy }\end{array}$ & $\begin{array}{c}\text { Babies with } \\
\text { both conditions }\end{array}$ & $\begin{array}{c}\text { Total } \\
\text { Controls } \\
\end{array}$ & \\
\hline $\mathrm{C} 4 \mathrm{~B} 2$ & $\begin{array}{c}8 / 38 \\
(21.0 \%)^{\mathrm{a}}\end{array}$ & $\begin{array}{c}14 / 66 \\
(21.2 \%)^{\mathrm{b}}\end{array}$ & $\begin{array}{c}5 / 18 \\
(27.8 \%)^{\mathrm{c}}\end{array}$ & $\begin{array}{c}27 / 122 \\
(22.1 \%)^{\mathrm{d}}\end{array}$ & $\begin{array}{l}35 / 356 \\
(10 \%)\end{array}$ \\
\hline $\begin{array}{l}{ }^{\mathrm{c}} p=0 \\
{ }^{\mathrm{b}} p=0 \\
{ }^{\mathrm{c}} p=0 \\
\mathrm{~d}^{\mathrm{c}} p=0\end{array}$ & $\begin{array}{l}\text { vs controls. } \\
3 \text { vs controls. } \\
\text { vs controls. } \\
09 \text { vs controls }\end{array}$ & 2.61 (95\% CI: 1. & 69). & & \\
\hline
\end{tabular}

GTGGGGACAATTCCAGAAGA-3' and antisense: 5'CCGAGCTGTCCAGGAATAAA-3'.

$H L A-D R B 1$ : a polymerase chain reaction sequence specific primer (PCR-SSP) technique was used to typed HLA-DRB1 at low resolution level [32].

\subsection{Statistical methods}

Comparisons of allele frequencies found in controls and children with $\operatorname{IgE}>0.35$, children with familial history of atopy and children with both conditions were made by means of $\chi^{2}$ or Fisher exact test as appropriate. The mean value of $\operatorname{IgE}$ at birth in babies carrying or not the allele C4B2A was compared using t-test for independent samples. A p value $<0.05$ was considered significant and multiple test correction was not applied since all significant association were retested in an independent sample of babies with appropriate control. All analysis were performed using STATA v 8.0 (StataCorp, College station, TX). Given the allelic frequency in the control sample and the power of the study for a true gene association of C4A and C4B alleles was $31 \%$ when $\mathrm{OR}=2,76 \%$ when $\mathrm{OR}=3$ and $99 \%$ when $\mathrm{OR}$ $=5$.

\section{Results}

We enrolled 2588 consecutive babies born at Neonatology Division of IRCCS Policlinico S. Matteo in Pavia (North Italy) whose parent signed informed con- sent: 256 had total $\mathrm{IgE}>0.35 \mathrm{KU} / \mathrm{l}$ at birth and during the follow-up (6 months and 1 year); 400 had familial history of atopy (at least one parent or sibling), while 135 were positive for both conditions (Fig. 1). All these 791 babies/2588 (30.6\%) were considered "at risk" for atopy and clinically followed-up whilst 1797 were negative both for IgE presence and familial history of atopy. The percentage of males and females in babies with $\mathrm{IgE}>0.35 \mathrm{KU} / \mathrm{l}$ was $52.7 \%$ and $47.3 \%$ respectively; among the hyperIgE infants with familiar history of atopy in $49 \%$ of cases the atopic parent was the mother, in the $41 \%$ was the father, in $8 \%$ both the parents were atopic; in the remaining $2 \%$ the familiarity was given by sibling. In nonhyperIge infants with familiar history of atopy in $35 \%$ of cases the atopic parent was the mother, in the $46 \%$ was the father, in $16 \%$ both the parents were atopic; in the remaining $3 \%$ the familiarity was given by sibling. Babies with atopic mothers are at higher risk of being hyperIgE at birth (OR $1.77 p=0.004$ ).

As shown in Table 1(a), no significant difference emerged for $\mathrm{C} 4 \mathrm{~A}$ alleles while the allele C4B2 was significantly more frequent in the sample of babies at risk (22.1\% vs $10 \% ; p<0.001)$. As shown in Table 1(b), the frequency of the allele C4B2 is particularly high in babies that presented both hyperIgE and familial history of atopy $(27.8 \%)$ while in babies with hyperIgE is $21.0 \%$, and 21.2 in babies with familial history of atopy. All these frequencies are significantly higher than in controls $(p=0.03, p=0.05$ and $p=0.003$ respectively). These data were confirmed in an independent 
Table 2

LTA, RAGE, TNFA, TNFRI, TNFRII and FCERB1 genotypes distribution

\begin{tabular}{|c|c|c|c|c|}
\hline Genotypes & Babies "at risk" & Controls & $\mathrm{P}$ & OR \\
\hline $\mathrm{LTA}+252 \mathrm{AA}$ & $2 / 35(5.7 \%)$ & $18 / 241(7.0 \%)$ & & \\
\hline $\mathrm{LTA}+252 \mathrm{AG}$ & $15 / 35(42.8 \%)$ & $107 / 241(44.0 \%)$ & & \\
\hline $\mathrm{LTA}+252 \mathrm{GG}$ & $18 / 35(51.4 \%)$ & $116 / 241(48.0 \%)$ & & \\
\hline $\begin{array}{l}\text { RAGE-374 AA } \\
\text { RAGE-374 AT } \\
\text { RAGE-374 TT }\end{array}$ & $\begin{array}{r}5 / 35(14.3 \%) \\
16 / 35(45.7 \%) \\
14 / 35(40.0 \%)\end{array}$ & $\begin{array}{l}49 / 213(23.0 \%) \\
97 / 213(45.5 \%) \\
67 / 213(31.5 \%)\end{array}$ & 0.89 & 1.14 \\
\hline $\begin{array}{l}\text { TNFA-308 GG } \\
\text { TNFA-308 GA } \\
\text { TNFA-308 AA }\end{array}$ & $\begin{array}{c}25 / 35(71.4 \%) \\
10 / 35(28.6 \%) \\
0\end{array}$ & $\begin{array}{c}185 / 241(76.8 \%) \\
53 / 241(22.0 \%) \\
3 / 241(1.2 \%)\end{array}$ & 0.42 & 1.45 \\
\hline $\begin{array}{l}\text { TNFRI+36 AA } \\
\text { TNFRI+36 AG } \\
\text { TNFRI+36 GG }\end{array}$ & $\begin{array}{c}13 / 35(37.1 \%) \\
22 / 35(62.9 \%) \\
0\end{array}$ & $\begin{array}{r}74 / 228(32.5 \%) \\
119 / 228(52.2 \%) \\
35 / 228(15.3 \%)\end{array}$ & 0.57 & 1.41 \\
\hline $\begin{array}{l}\text { TNFRII+196 MM } \\
\text { TNFRII+196 MR } \\
\text { TNFRII+196 RR }\end{array}$ & $\begin{array}{c}18 / 35(51.4 \%) \\
15 / 35(42.9 \%) 2 \\
2 / 35(5.7 \%)\end{array}$ & $\begin{array}{c}104 / 190(54.7 \%) \\
75 / 190(39.5 \%) \\
11 / 190(5.8 \%)\end{array}$ & 0.044 & infinite \\
\hline $\begin{array}{l}\text { FCERB1-109 CC } \\
\text { FCERB1-109 CT } \\
\text { FCERB1-109 TT }\end{array}$ & $\begin{array}{l}21 / 57(36.8 \%) \\
22 / 57(38.6 \%) \\
14 / 57(24.6 \%)\end{array}$ & $\begin{array}{l}38 / 147(25.8 \%) \\
62 / 147(42.2 \%) \\
47 / 147(32.0 \%)\end{array}$ & & \\
\hline & & & $0.27^{*}$ & 1.44 \\
\hline
\end{tabular}

* Subdividing babies in three categories: babies with familial history of atopy: significantly higher frequency of CC genotype (12/27, $44.4 \%$ vs $25.8 \% p=$ $0.05)$; babies with $\operatorname{IgE}>0.35 \mathrm{KU} / \mathrm{l}$ : no significant difference was observed (5/18 $27.8 \%$ I vs $27.8 \%$ ) babies with both conditions: no significant difference was observed (4/12 $33.3 \%$ vs $27.8 \%)$.

sample of other 34 babies (gene frequency of C4B2 in babies at "risk" $20 \%$ vs $9 \%$ in cord blood donors, $p=$ 0.0036 , OR 2.78, 95\%CI 1.26-5.92). Furthermore, the mean value of $\operatorname{IgE}$ at birth in babies carrying the allele C4B2 was $2.26 \mathrm{KUA} / 1$ versus $0.74 \mathrm{KUA} / 1$ in those not carrying this allele $(p=0.01)$.

At the follow-up visit, scheduled at 12 months, a first group of these babies was typed for RAGE, LTA, TNFA and TNFRI and TNFRII. As shown in Table 2, the only significant difference is represented by TNFRI polymorphism were the genotype GG is absent in babies "at risk". To confirm our findings we retested the association in an independent sample of other 23 babies at risk presenting at the follow-up of 12 months of age. In this group the difference was no longer significant (Table 3).

Although no significant difference emerges between the whole sample of babies "at risk" and controls (Table 2), the polymorphism $-10^{9}$ in the promotor region of FCERB 1 showed in babies with familial history of atopy a higher frequency of CC genotype (12/27,44.4\% vs $25.8 \% p=0.05)$, while no difference was observed in babies with $\mathrm{IgE}>0.35 \mathrm{KU} / \mathrm{l}$ and in babies with both conditions (5/18 27.8\% and 4/12 $33.3 \%$ respectively vs $38 / 14725.8 \%$ in controls).
Table 3

TNFRI $+36 \mathrm{G}>\mathrm{A}$ polymorphism in an independent sample of 23 babies at risk

\begin{tabular}{crcc}
\hline Genotypes & Babies at risk & Cord blood donors & $\mathrm{p}$ \\
\hline AA & $10 / 23(43.5 \%)$ & $51 / 153(33.3 \%)$ & \\
AG & $10 / 23(43.5 \%)$ & $79 / 153(51.7 \%)$ & \\
GG & $3 / 23(13.0 \%)$ & $23 / 153(15.0 \%)$ & \\
& & & 0.63 \\
\hline
\end{tabular}

As shown in Fig. 2, investigating families, a common recurrent haplotype was not found but we noticed the alleles (inherited by the allergic parent along with C4B2) DRB1*01, *03 and *1001. These alleles were recently shown to be associated to a high serum level of $\operatorname{IgE~[33]~in~a~white~population~from~the~Australian~}$ rural town of Busselton. The allergic parent was the mother in 3 out 4 cases; although the number of families is limited this finding could suggest to investigate a underlying parent-of-origin effect that could be in common with other immune disorders [34-37].

\section{Conclusion}

Identifying the genes underlying atopy status could be useful to better understand its pathogenesis and to 

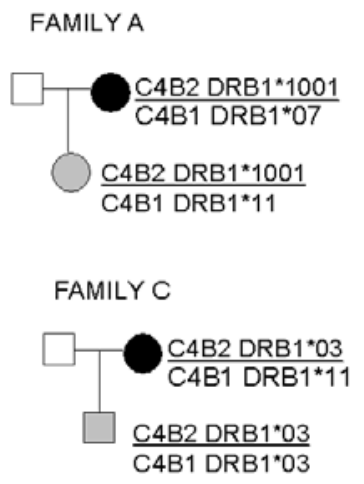

FAMILYB

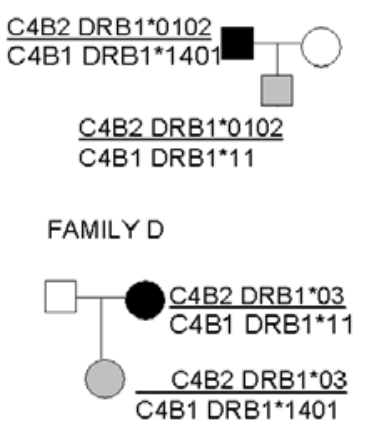

Fig. 2. Family sample. The black symbols indicate an atopic subject, the grey ones a hyper IgE infant.

improve preventive strategies and therapies. Different chromosomal regions containing genes influencing atopy have been so far analyzed and several candidate gene polymorphisms have been investigated. Our study shows that $\mathrm{C} 4 \mathrm{~B}$ gene could be involved in familial predisposition to atopy, although we cannot exclude that the high frequency of C4B2 allele could just act as a marker for other closely linked gene(s). C4B2 is not known as a functionally deficient allele; but it was associated with some autoimmune disease as uveitis [17] and diabetes [18]. C4 plays a fundamental role in antibody production as showed in hamsters, in transgenic mice experiments and in man relatively to the antiHBV vaccine nonresponsiveness [19-22]. C4 serum protein is involved in immunocomplexes destruction, and since asthma patients were shown to have high levels of immunocomplexes a suggestive hypothesis could be that the $\mathrm{C} 4 \mathrm{~B} 2$ allele was impaired in this function. On the other hand the C4B2 allele could act simply as a marker: that is why we considered linked genes as the telomeric ones TNFA/LTA and the centromeric gene RAGE [27]. Non-HLA polymorphic genes as TNFRI and TNFRII were also analysed because functionally strictly related. No significant association was observed. Although merely speculative since the small number of families investigated, the family study could suggest that it could be interesting to investigate the HLA region between class II and III. Also regarding FCERB1 gene we did not find significant association except for babies with familial history of atopy (Table 2 , footnote), differently from what reported by others: FCERB1 gene was strongly associated with asthma and hyperproduction of IgE in Japanese and Australian aborigenes [23,24].
We are following-up these babies in a precise program to evaluate a possible correlation with clinical development of overt atopic disease later in life. At present we have not children with atopic problems.

\section{Acknowledgments}

This study was partially granted by the grant Ricerca Corrente 2001 "Identificazione precoce del neonato a rischio di atopia" of IRCCS Policlinico S. Matteo, Pavia, Italy.

\section{References}

[1] U. Wahn, R.L. Bergmann and R. Nickel, Early life markers of atopy and asthma, Clin Exp Allergy 28 (1998), 20-21.

[2] I. Lehman, A. Thoelke, M. Weiss et al., T cell reactivity in neonates from an East and a West German city-results of the LISA study, Allergy 57 (2002), 129-136.

[3] M.L. Tang, A.S. Kemp, J. Thorburn and D.J. Hill, Reduced interferon-gamma secretion in neonates and subsequent atopy, Lancet 344 (1994), 983-985.

[4] A. Haagerup, T. Bierke, P.O. Schiøtz, H.G. Binderup, R. Dahl and T.A. Kruse, Asthma and atopy - a total genome scan for susceptibility genes, Allergy 57 (2002), 680-686.

[5] M. Cuccia Belvedere, V. Monafo, M. Martinetti, A. Plebani, F. De Paoli and G.R. Burgio, Recurrent extended HLA haplotypes in children with selective IgA deficiency, Tissue Antigen 34 (1989), 127-132.

[6] M.A. Modica, S. Freddi and C. Caruso, Blood IgA, IgM and IgE levels are influenced by sex and HLA phenotype, Exp Clin Immunogenet 6(4) (1989), 251-257.

[7] A.H. Mansur, G.A. Williams, D.T. Bishop et al., Evidence for a role of HLA DRB1 alleles in the control of IgE levels, strengthened by interacting TCR A/D marker alleles, Clin Exp Allergy 30 (2000), 1371-1378. 
[8] W.M. Howell, P. Standring, J.A. Warner and J.O. Warner, HLA class II genotype, HLA-DR B cell surface expression and allergen specific IgE production in atopic and non-atopic members of asthmatic family pedigrees, Clin Exp Allergy 29 (1999), 35-38.

[9] M. Moffat and W.O. Cookson, Tumor necrosis factor haplotypes and asthma, Hum Mol Genet 6 (1997), 551-554.

[10] T.C. Li Kam Wa, A.H. Mansur, J. Britton et al., Association between -308 tumor necrosis factor promoter polymorphism and bronchial hyperreactivity in asthma, Clin Exp Allergy 29 (1999), 1204-1208.

[11] W.O.C. Cookson, Asthma genetics, Chest 121 (2002), 7S$13 \mathrm{~S}$.

[12] T. Xie, L. Rowen, B. Aguado et al., Analysis of the genedense major histocompatibility complex class III region and its comparison to mouse, Genome Research 13 (2003), 26212636.

[13] C.Y. Yu, Molecular genetics of the human MHC complement gene cluster, Exp Clin Immunogenet 15 (1998), 213-230.

[14] C.Y. Yu, E.K. Chung, Y. Yang et al., Dancing with complement C4 and the RP-C4-CYP21-TNX (RCCX) modules of the MHC, Progr Nucleic Acid Res Mol Biol 75 (2003), 217-292.

[15] M. Lenzi, M. Frisoni, V. Mantovani et al., Haplotype HLAB8 -DR3 confers susceptibility to hepatitis C virus-related mixed cryoglobulinemia, Blood 91 (1998), 2062-2066.

[16] K. Hartung, M.P. Baur, R. Coldeway et al., MHC haplotypes and complement $\mathrm{C} 4$ alleles in systemic lupus erythematosus, J Clin Invest 90 (1992), 1346-1351.

[17] D. Wakefield, R. Buckley, J. Golding et al., Association of complement allotype C4B2 with anterior uveitis, Hum Immunol 21 (1998), 233-237.

[18] K. Lhotta, M. Auinger, F. Kronenberg, K. Irsigler and P. Konig, Polymorphism of complement $\mathrm{C} 4$ and susceptibility to IDDM and microvascular complications, Diabetes Care 19 (1996), 53-55.

[19] O. Finco, S. Li, M. Cuccia, F.S. Rosen and M.C. Carroll, Structural differences between the two human complement C4 isotypes affect the humoral immune response, J Exp Med 175 (1992), 537-543.

[20] M.C. Carroll and M.B. Fisher, Complement and the immune response, Curr Opin Immunol 9 (1997), 64-69.

[21] M. Martinetti, A. De Silvestri, C. Belloni et al., Humoral response to recombinant hepatitis $\mathrm{B}$ virus vaccine at birth: role of HLA and beyond, Clin Immunol 97 (2000), 234-240.

[22] A. De Silvestri, A. Pasi, M. Martinetti et al., Family study of non-responsiveness to hepatitis B vaccine confirms the importance of HLA class III C4A locus, Gen \& Immun 2 (2001), 367-372.

[23] T. Shirakawa, X.Q. Mao, S. Sasaki et al., Association between Fc Epsilon R1 Beta and atopic disorder in a Japanese population, Lancet 347 (1996), 394-395.

[24] L.J. Palmer, P.D. Pare, J.A. Faux et al., Fc Epsilon R1 Beta polymorphism and total serum IgE levels in endemically parasitized in Australian aborigenes, Am J Hum Genet 61 (1997), 182-188.
[25] G. Mauff, B. Luther, P. Schneider et al., Reference typing report for complement component C4, Exp Clin Immunogenet 15 (1998), 249-260.

[26] K. Ozaki, Y. Ohnishi, A. Iida et al., Functional SNPs in the lymphotoxin-alpha gene that are associated with susceptibility to myocardial infarction, Nat. Genet. 32 (2002), 650-654.

[27] B.I. Hudson, M.H. Stickland, T.S. Futers and P.J. Grant, Effects of novel polymorphisms in the RAGE gene on trascriptional regulation and their association with diabetic retinopathy, Diabetes 50 (2001), 1505-1511.

[28] S. Sakao, K. Tatsumi, H. Igari, Y. Shino, H. Shirasawa and T. Kuriyama, Association of tumor necrosis factor alpha gene promoter polymorphism with the presence of chronic obstructive pulmonary disease, Am J Respir Crit Care Med 163 (2001), 420-442.

[29] S.A. Pitts, O.O. Olomolaiye, C.J. Elson, C.I. Westacott and J.L. Bidwell, An MspA1 I polymorphism in exon 1 of the human TNF receptor type I (p55) gene, Eur J Immunogenet 25 (1998), 269-270.

[30] A.S. Al-Ansari, W.E. Ollier, J. Villareal, J. Ordi, L.S. Teh and A.H. Hajeer, Tumor necrosis factor receptor II (TNFRII) exon 6 polymorphism in systemic lupus erythematosus, Tissue Antigens 55 (2000), 97-99.

[31] N. Hizawa, E. Yamaguchi, E. Jinushi and Y. Kawakami, A commom FCERB1 gene promoter polymorphism influences total serum IgE levels in a Japanese population, Am J Respir Crit Care Med 16 (2000), 906-909.

[32] O. Olerup and H. Zetterquist, HLA-DR typing by PCR amplification with sequence-specific primers (PCR-SSP) in 2 hours: an alternative to serological DR typing in clinical practice including donor-recipient matching in cadaveric transplantation, Tissue Antigens 39(5) (May 1992), 225-235.

[33] M.F. Moffatt, C. Schou, J.A. Faux, G.R. Abecasis, A. James, A.W. Musk and W.O. Cookson, Association between quantitative traits underlying asthma and the HLA-DRB1 locus in a family-based population sample, Eur J Hum Genet 9 (2001), 341-346.

[34] J.H. Warram, A.S. Krolewsky, M.S. Gottleb et al., Differences in risk of insuline-dependent diabetes in offsprings of diabetes mothers and diabetes fathers, NEJM 311 (1984), 149-152.

[35] Y. Koumantaki, E. Giziaki, A. Linos et al., Family history as a risk factor for rheumatoid arthritis: a case-control study, $J$ Rheumatol 24 (1997), 1522-1526.

[36] P.N. Akolkar, B. Gulwand-Akolkar, D. Heresbach et al., Differences in risk of Crohn's disease in offspring of mothers and fathers with inflammatory bowel disease, Am J gastroenterol 92 (1997), 2241-2244.

[37] I. Vorechovsky, A.D. Webster, A. Plebani et al., Genetic linkage of IgA deficiency to the major histocompatibility complex; evidence for allele segregation distortion, parent-oforigin penetrance differences and the role of anti-IgA antibodies in disease predisposition, Am J Hum Genet 64 (1999), 1096-1109. 


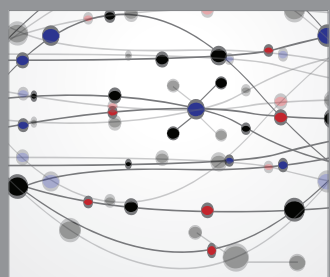

The Scientific World Journal
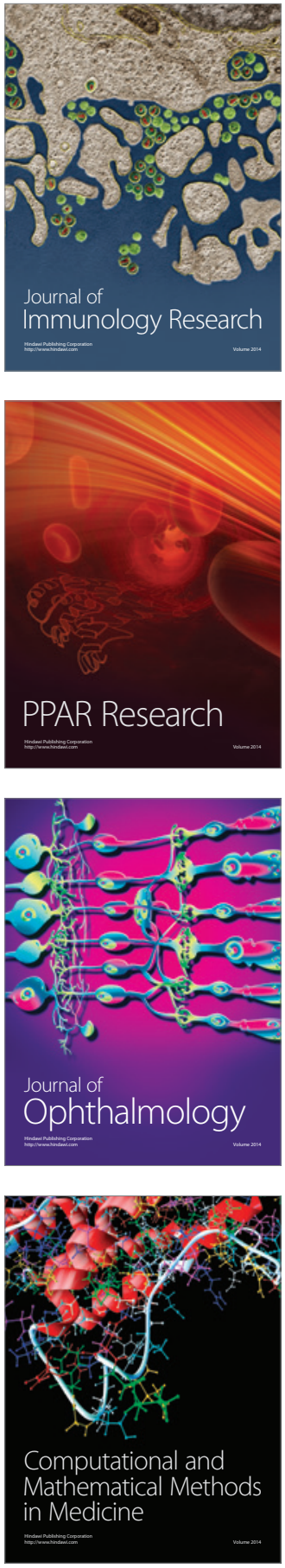

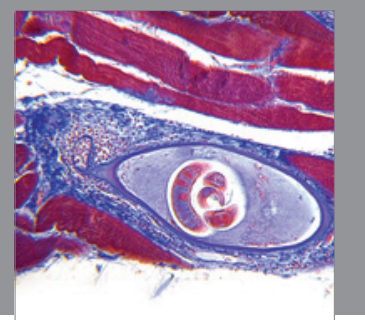

Gastroenterology

Research and Practice
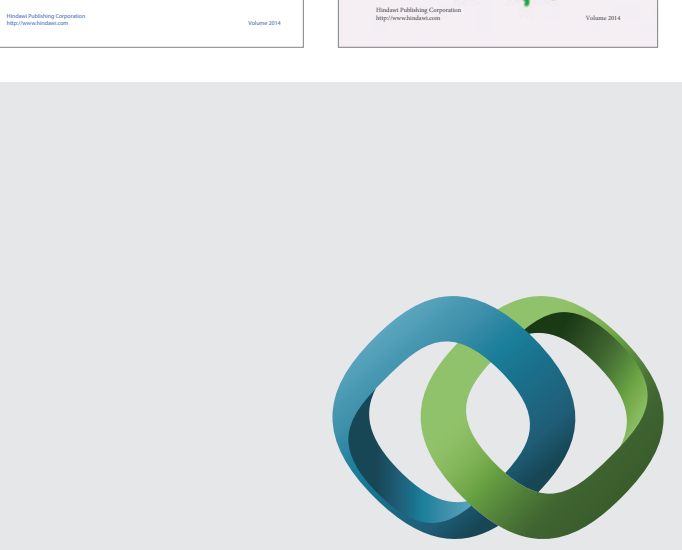

\section{Hindawi}

Submit your manuscripts at

http://www.hindawi.com
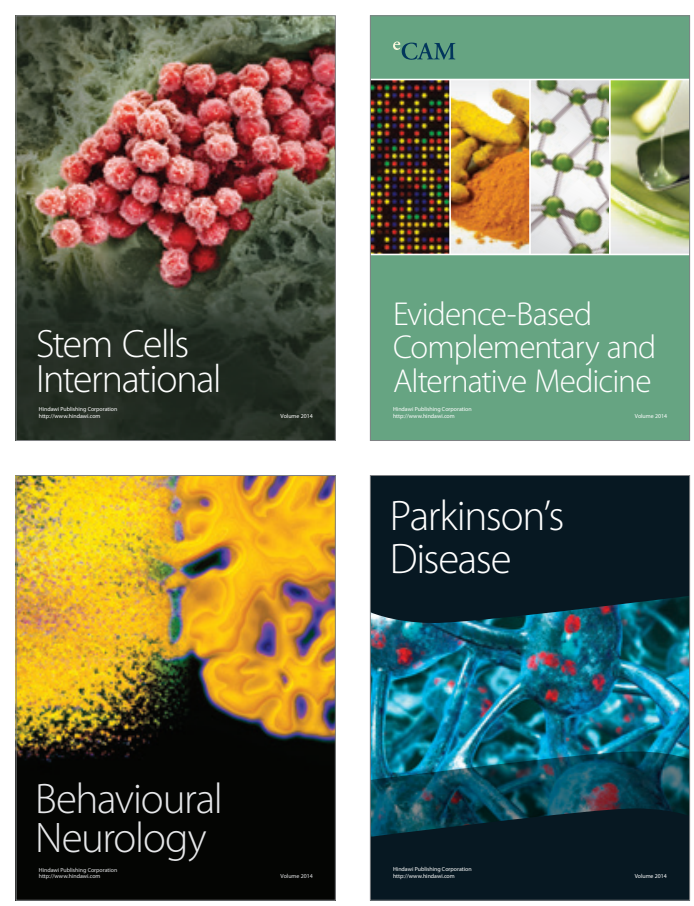

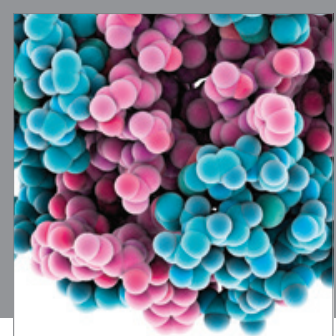

Journal of
Diabetes Research

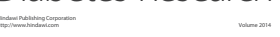

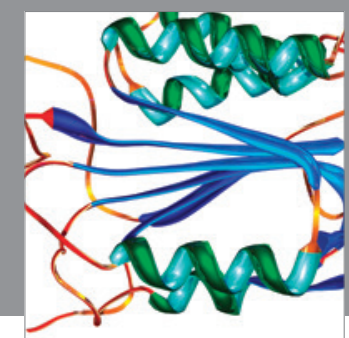

Disease Markers
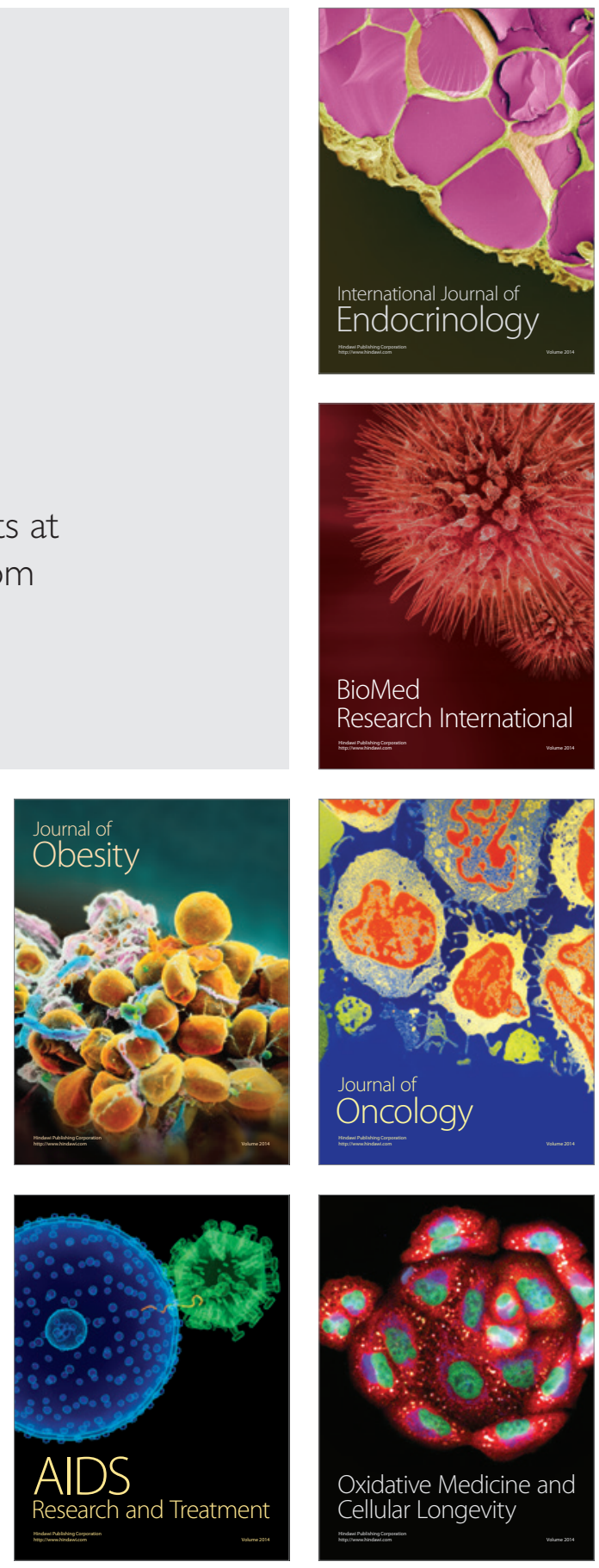